\title{
Exploring the submarine Graham Bank in the Sicily Channel
}

\author{
Mauro Coltelli ${ }^{1,{ }^{\star}}$, Danilo Cavallaro ${ }^{1,2}$, Giuseppe D’Anna ${ }^{3}$, Antonino D’Alessandro ${ }^{3}$, \\ Fausto Grassa $^{4}$, Giorgio Mangano ${ }^{3}$, Domenico Patanè ${ }^{1}$, Stefano Gresta ${ }^{2,5}$ \\ ${ }^{1}$ Istituto Nazionale di Geofisica e Vulcanologia, Osservatorio Etneo, Catania, Italy \\ ${ }^{2}$ Università di Catania, Dip. di Scienze Biologiche, Geologiche e Ambientali, Sezione di Scienze della Terra, Catania, Italy \\ ${ }^{3}$ Istituto Nazionale di Geofisica e Vulcanologia, Centro Nazionale Terremoti, Rome, Italy \\ ${ }^{4}$ Istituto Nazionale di Geofisica e Vulcanologia, Sezione di Palermo, Palermo, Italy \\ ${ }^{5}$ Istituto Nazionale di Geofisica e Vulcanologia, Rome, Italy
}

Article history
Received November 19, 2015; accepted February 19, 2016.
Subject classification:
Graham Bank, Ferdinandea, Multibeam bathymetry, OBS, ROV, Underwater volcanism.

\begin{abstract}
In the Sicily Channel, volcanic activity has been concentrated mainly on the Pantelleria and Linosa islands, while minor submarine volcanism took place in the Adventure, Graham and Nameless banks. The volcanic activity spanned mostly during Plio-Pleistocene, however, historical submarine eruptions occurred in 1831 on the Graham Bank and in 1891 offshore Pantelleria Island. On the Graham Bank, 25 miles SW of Sciacca, the 1831 eruption formed the short-lived Ferdinandea Island that represents the only Italian volcano active in historical times currently almost completely unknown and not yet monitored. Moreover, most of the Sicily Channel seismicity is concentrated along a broad NS belt extending from the Graham Bank to Lampedusa Island. In 2012, the Istituto Nazionale di Geofisica e Vulcanologia (INGV) carried out a multidisciplinary oceanographic cruise, named "Ferdinandea 2012", the preliminary results of which represent the aim of this paper. The cruise goal was the mapping of the morpho-structural features of some submarine volcanic centres located in the northwestern side of the Sicily Channel and the temporary recording of their seismic and degassing activity. During the cruise, three OBS/Hs (ocean bottom seismometer with hydrophone) were deployed near the Graham, Nerita and Terribile submarine banks. During the following 9 months they have recorded several seismo-acoustic signals produced by both tectonic and volcanic sources. A high-resolution bathymetric survey was achieved on the Graham Bank and on the surrounding submarine volcanic centres. A widespread and voluminous gas bubbles emission was observed by both multibeam sonar echoes and $a$ ROV (remotely operated vehicle) along the NW side of the Graham Bank, where gas and seafloor samples were also collected.
\end{abstract}

\section{Introduction and geodynamic framework of the Sicily Channel}

Within the geodynamic framework of the central Mediterranean area, the Sicily Channel belongs to the central portion of the northern margin of the African continental plate, called Pelagian Block [Burollet et al. 1978]. It corresponds to the foreland area of the Sicilian sector of the Neogene Apenninian-Maghrebian fold-andthrust belt, the outermost and youngest thrust sheet of which is represented by the Gela Nappe [Ogniben 1969] (Figure 1). The Sicily Channel consists of a 6-7 km thick Mesozoic-Cenozoic shallow to deep water carbonate sedimentary successions, with repeated intercalations of volcanics [Torelli et al. 1995], covered by Upper Tortonian-Lower Messinian siliciclastic deposits and PlioQuaternary clastic sequences.

The tectonic setting of the Sicily Channel is the product of the Neogene continental collision between the African and European plates and of the NeogeneQuaternary NW-trending rift [Jongsma et al. 1985, Boccaletti et al. 1987, Reuther et al. 1993].

The presence of an intraplate rift in a foreland area, in front of a collisional belt, is not a common tectonic scenario and the geodynamic mechanism producing the Sicily Channel rift as well as the relationships between tectonics and magmatism in this area have not yet been completely clarified. The Sicily Channel is considered as a dextral shear zone and its main tectonic depressions as large pull-apart basins involving deep crustal levels [Finetti 1984, Jongsma et al. 1985, Reuther and Eisbacher 1985, Ben-Avraham et al. 1987, Boccaletti et al. 1987, Cello 1987]. A mechanism of intraplate rift related to NE-SW directed displacement of Sicily away from Africa, has been also proposed by Illies [1981]. Argnani [1990] interpreted the rifting as caused by a lateral mantle convection developed during the roll-back 


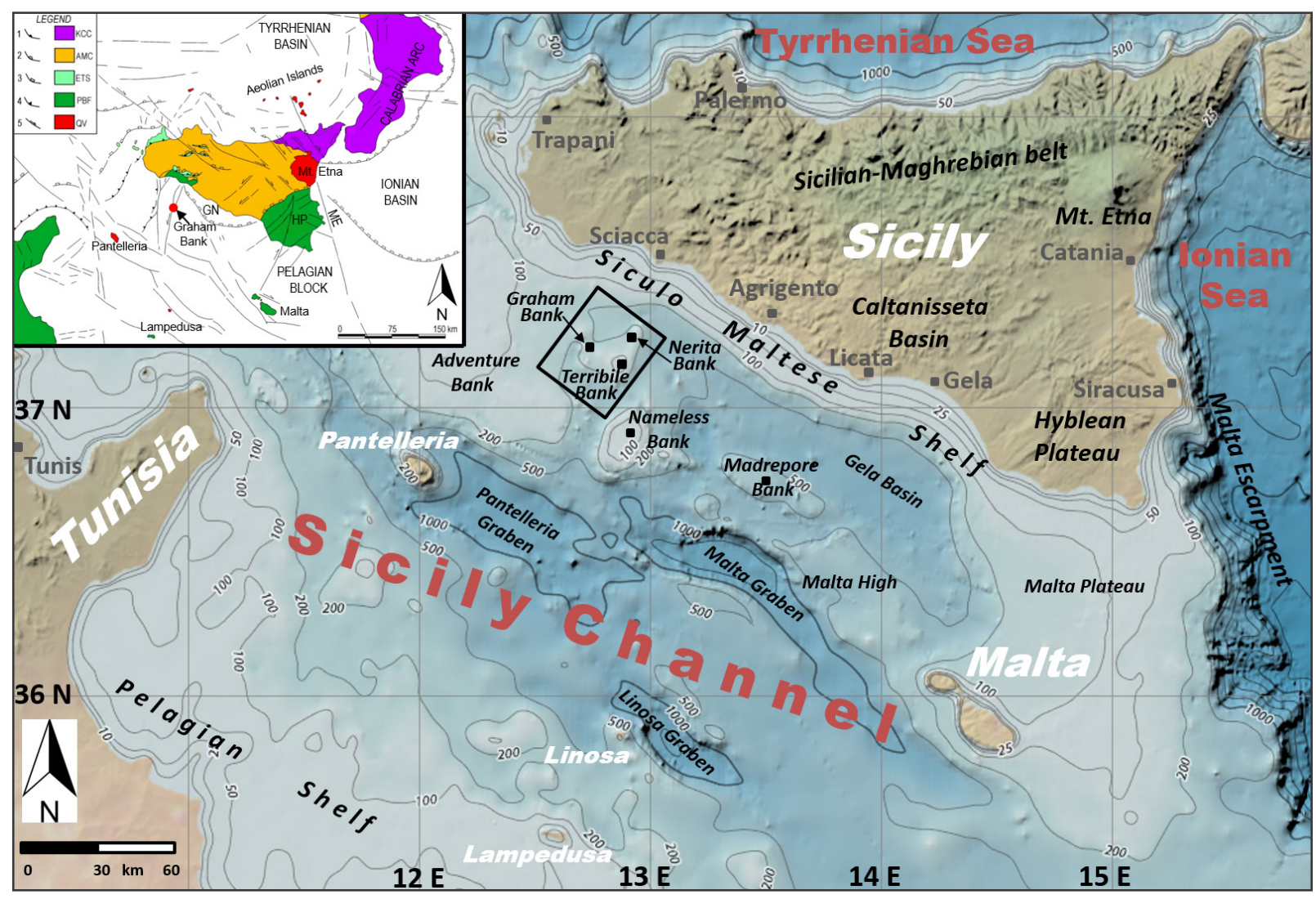

Figure 1. Bathymetric map of the Sicily Channel (bathymetry from Gebco - General bathymetric chart of the oceans). The black box displays the study area. The inset shows the structural setting of central Mediterranean Sea (modified from Lentini et al. [2006]): (1) Overthrust of the Sardinian block upon Kabilo-Calabride (KCC) units; (2) Overthrust of the KCC units upon the Apennine-Maghrebian Chain (AMC); (3) External front of AMC upon the foreland units and the external thrust system (ETS); (4) Thrust front of ETS; (5) Main normal and strikeslip faults. PBF: Pelagian block foreland units; QV: Quaternary volcanoes; ME: Malta Escarpment; HP: Hyblean Plateau; GN: Gela Nappe.

of the African lithosphere slab beneath the Tyrrhenian Basin. Recently, Corti et al. [2006] hypothesize the occurrence of two independent tectonic processes in the western side of the Sicily Channel: the NW-SE shortening related to the Sicilian-Maghrebian accretion and a NE-SW extension, acting simultaneously and overlapping each other.

Most earthquakes of the Sicily Channel are focused along a broad NS oriented belt extending from Lampedusa Island to southwestern Sicily coast passing through the Graham Bank [Cello 1987, Argnani 1990, Rotolo et al. 2006, Civile et al. 2010, Calò and Parisi 2014] (Figure 1). Inside this belt the alkaline volcanic centres of Linosa Island, and the Nameless and Graham banks are also located. This belt was interpreted as a strike-slip transfer fault zone between two segments of the rift system, Pantelleria Graben to the west and the Malta and Linosa grabens to the east [Argnani 1990, Civile et al. 2008].

This work describes the scientific activity and the preliminary results of the oceanographic cruise named "Ferdinandea 2012" carried out offshore southwestern Sicily. The main objective of the survey was the assessment of volcanic and seismic hazard in the area close to populous Sicilian coast. The final goal of this prelimi- nary activity was to achieve, in the medium period, the permanent monitoring of the offshore area integrating the data collected by the multidisciplinary sensors deployed on the seafloor with those recorded by the Istituto Nazionale di Geofisica e Vulcanologia (INGV) monitoring network installed inland.

\section{Volcanic and seismic activity}

A widespread volcanic activity is known to have occurred in the Sicily Channel during Plio-Pleistocene times [Calanchi et al. 1989] building up Linosa and Pantelleria islands where the volcanic products are well exposed. Nevertheless, the oldest magmatic products of the Sicily Channel, with an age of $9.5 \pm 0.4 \mathrm{Ma}$, have been found in the Nameless Bank [Beccaluva et al. 1981]. Geophysical and petrological data revealed the presence of minor submarine volcanism in the Adventure, Nameless, Graham and Terribile banks [Colantoni et al. 1975, Beccaluva et al. 1981, Calanchi et al. 1989, Rotolo et al. 2006]. The volcanic activity continued until historical time, testified by the most recent underwater eruptions occurred in 1891, some $4 \mathrm{~km} \mathrm{NE}$ of Pantelleria Island [Washington 1909, Conte et al. 2014], and in 1831 on the Graham Bank, producing an ephemeral volcanic is- 
land named Ferdinandea (Figure 2). The 1831 eruption lasted one month and a half, forming, 25 miles SW of Sciacca, the small island of Ferdinandea (300 m large and $60 \mathrm{~m}$ high) composed of loose tephra that was easily eroded by wave activity during the next three months [Gemmellaro 1831, Marzolla 1831].

Sicily Channel rift and southwestern Sicily show some different seismo-tectonic behaviours [Meletti et al. 2008]. The strongest earthquakes occurred in 1968 inland Sicily on the Belice Valley (Figure 3), when six events with magnitudes ranging from 5.2 to 6.1 strongly damaged several towns, causing more than three hundred casualties [Guidoboni et al. 2007]. Along the SW Sicily coast, the seismicity is characterized by low magnitude seismic events affecting mostly the area of Sciacca [Rigano et al. 1998]. Earthquakes with magnitude not exceeding 5.1 occurred in 1578, 1652, 1724, 1727, 1740 and 1817; they were probably located offshore, not far from the coast [Rovida et al. 2011].

Since an offshore seismic swarm, with some earthquakes felt along the southern coast of Sicily, occurred two weeks before of the 1831 eruption [Falzone et al. 2009], a relationship between seismic and volcanic activity in the Sicily Channel is suggested. Moreover, some evidences of ancient earthquakes that damaged the Greek-Roman town of Selinunte, located on the coast $25 \mathrm{~km}$ NW of Sciacca, are provided by archaeological investigations, which dated two events around 400-200 B.C and 400-1200 A.D. [Guidoboni et al. 2002, Bottari et al. 2009].

The seismicity recorded in the last thirty years in the Sicily Channel by the Italian National Seismic Network, operated by INGV (Figure 3; from ISIDE: Italian seismological instrumental and parametric database, http: / / iside.rm.ingv.it) is relatively frequent but characterized by low magnitudes (mainly $\mathrm{M}<4$ ). Only a few events have been localized near the Graham Bank; until now this gap of seismicity was considered due to the not optimal distribution of the seismic stations that are located only in the Sicily mainland and in the Pantelleria, Lampedusa and Linosa islands [D'Alessandro et al. 2011]. Recently, Calò and Parisi [2014] suggest that this gap might be generated by a tectonic discontinuity in the N-S transfer fault zone previously identified in the Sicily Channel (Figure 3). Nevertheless, a significant seismicity is discontinuously concentrated along this broad NS belt showing large seismic gaps in proximity of the Graham Bank.

\section{The oceanographic cruise}

Between July 17 and 21, 2012, INGV carried out a multidisciplinary oceanographic cruise, named "Ferdinandea 2012", on the NW sector of the Sicily Channel.

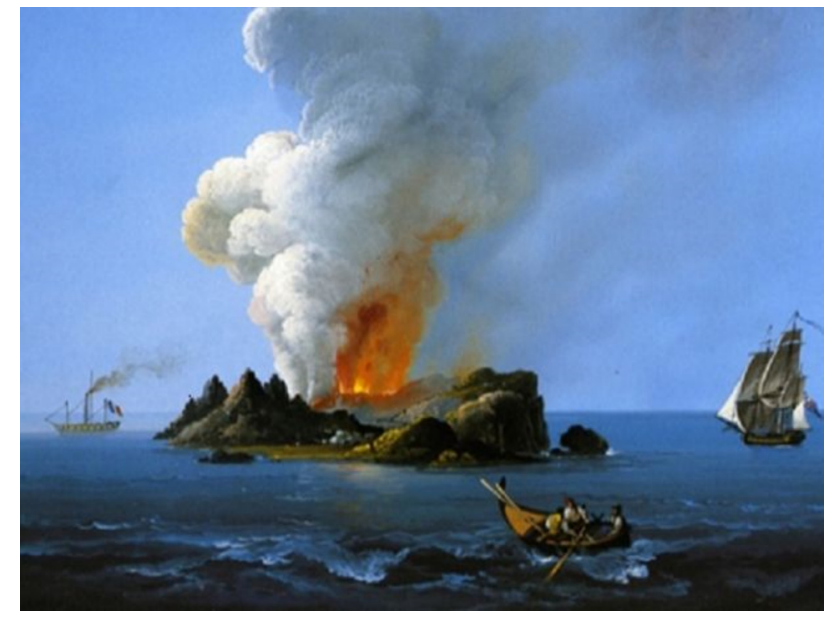

Figure 2. One of the several paintings by the French painter Edmond Joinville showing the 1831 eruption forming Ferdinandea Island.

The main goals of the cruise were the monitoring of the potential seismogenic tectonic structures around the Graham, Terrible and Nerita submarine banks, the geochemical survey to localize fumarole fields and sample gas risings, and the bathymetric mapping of the Graham Bank and surrounding submarine volcanic centres. Three sections of the INGV were involved within the research activity: (i) Osservatorio Etneo of Catania for the submarine volcanism and the volcano seismology; (ii) OBS-Lab of Centro Nazionale Terremoti (National earthquake centre), located at the Gibilmanna observatory near Palermo, for the seismo-acoustic monitoring using three OBS/Hs; (iii) Palermo section for the geo-

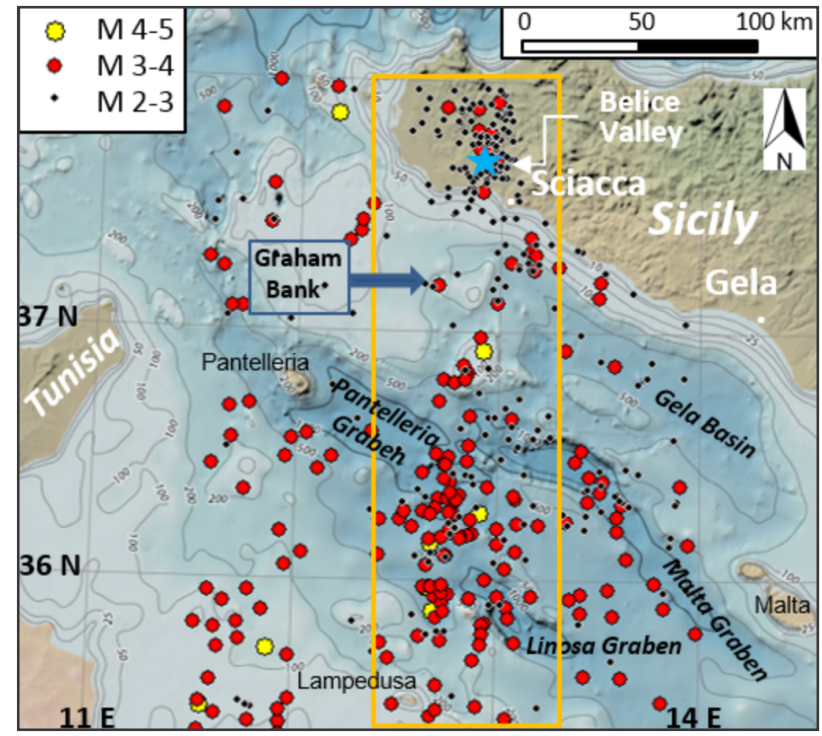

Figure 3. The distribution of earthquakes epicentres recorded between 1985 to 2015 in the centralwestern side of the Sicily Channel and inland, along the Belice Valley (data from ISIDE: Italian seismological instrumental and parametric database, http:/ / iside. $\mathrm{rm}$.ingv.it). The blue star shows the location of the strong seismic sequence of the Belice earthquake. The orange box images a NS belt were the seismicity is highly concentrated. (Bathymetry from Gebco - General bathymetric chart of the oceans). 
chemical analysis of the volcanic gas. The cruise was performed on the Research Vessel (R/V) Astrea by ISPRA (Istituto Superiore per la Protezione e la Ricerca Ambientale) operated by So.Pro.Mar. S.p.A., and was conducted as part of the program of extension to the Italian sea of geophysical and geochemical monitoring of the Italian active volcanoes. The survey, mainly focused on the Graham Bank, was also carried out on the neighbouring Terrible and Nerita banks that form, together with the Graham Bank, a large submarine high [Colantoni et al. 1975, Falzone et al. 2009] rising from 250 to $500 \mathrm{~m}$ from the surrounding seafloor (Figure 1).

The high-resolution seafloor mapping covered an area of some $100 \mathrm{~km}^{2}$ about $50 \mathrm{~km}$ offshore Sciacca town on the SW Sicily coast. It was performed by using an EM 2040 Kongsberg 200-400 kHz multibeam sonar system supported by GPS-RTK positioning. Daily sound speed profiles and repeated calibration of transducers were applied during the survey to get the better data resolution as possible. The SIS and CARIS Hips and Sips software packages were used for data acquisition and processing, respectively, allowing to obtain a very high resolution DTM (digital terrain model) of the seafloor.

During the cruise, three OBS/Hs (ocean bottom seismometer with hydrophone; Mangano et al. [2011]) were deployed near the three banks, in order to detect low energy seismo-volcanic and hydrothermal activity (Figures 4 and 5). Each OBS/H was equipped with a 3C broadband seismometer, Guralp CMG40T-OBS model, having a flat transfer function into the band $60 \mathrm{~s}-100 \mathrm{~Hz}$. The sensor, housed in a titanium sphere designed to operate at a depth of up to $6000 \mathrm{~m}$, was equipped with an autoleveling system, which enables high precision sensor leveling. The OBS/Hs were also equipped with a hydrophone HighTechInc HTI-04-PCA/ULF with a flat transfer function in the frequency band $100 \mathrm{~s}-8 \mathrm{kHz}$. The signals (velocity and pressure signals) were acquired by a Send Geolon-MLS four-channels 21 bit datalogger, at a sampling rate of $200 \mathrm{~Hz}$. Internal clock synchronization was made on board just before the OBS/Hs deployment.

Some ROV (remotely operated vehicle) dives were carried out by using the ROV PolluxII by GEI (400 m depth rated), equipped with a manipulator, that allowed us to collect several video on the main submarine volcanic centres, a seafloor rock sample and a gas sample from a fumarole field located along the NW side of the Graham Bank (Figure 4). In order to control in real time the correct deployment on the sea bottom of the seismometer from the arm of the OBS/H, two ROV dives were also performed (Figure 5).

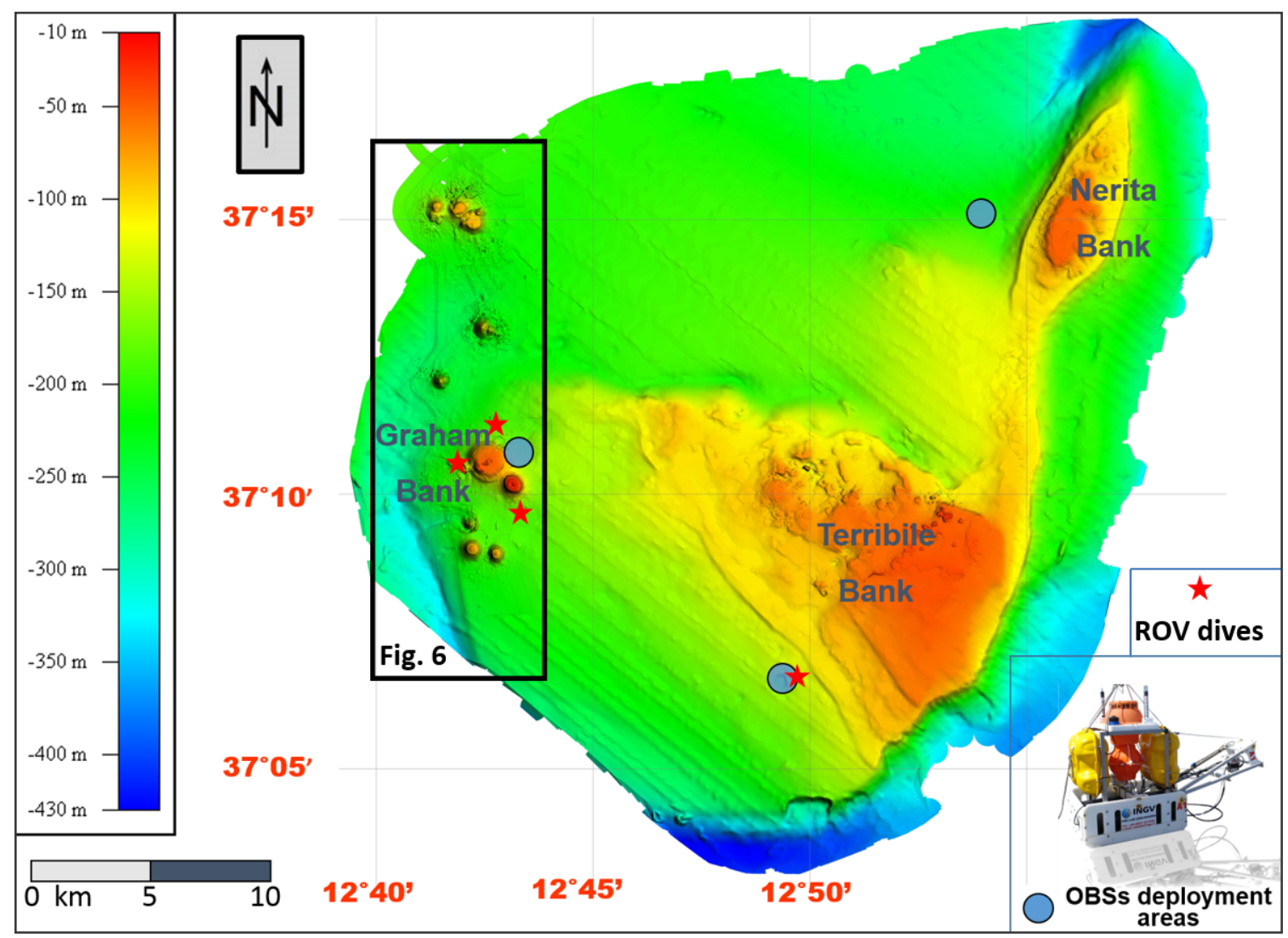

Figure 4. Bathymetric map of the three banks located offshore the southwestern coast of Sicily (the bathymetric data of the Nerita and Terribile banks have been provided by the Istituto Idrografico della Marina Italiana), with location of the OBS/Hs deployment areas and ROV dives. The black box represents the area of Figure 6 . 


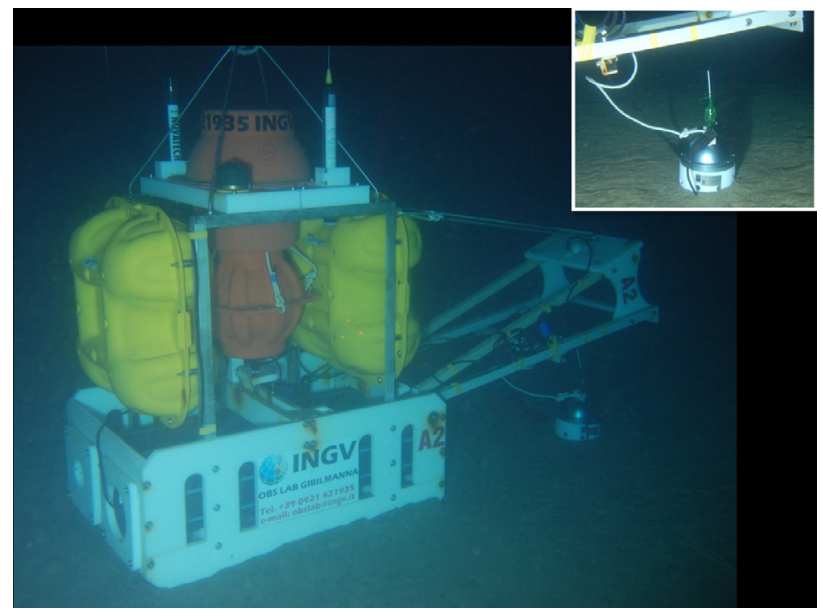

Figure 5. The OBS deployed near the Terribile Bank; the deployment on seabed of its seismometer was filmed from the ROV of R/V Astrea; inset on the top right shows a close-up of the titanium sphere housing the seismometer.

\section{Morphological analysis of the new bathymetric map}

The high-resolution seafloor mapping obtained from the "Ferdinandea 2012" cruise, together with the bathymetric data provided by the Istituto Idrografico della Marina (Italian Navy hydrographic office), allows us to better define the morphological rise located offshore southwestern Sicily including the Graham, Nerita and Terribile banks (Figure 1). This high shows a triangular shape with the maximum axis (30 km long) oriented NE-SW and is bounded by steep scarps especially on the SW and E sides (Figure 4). It is characterized by a very irregular bathymetry with a pretty shallow seafloor interrupted by a succession of topographic highs. The shallowest points are located on the Nerita Bank $(-50 \mathrm{~m})$ to the north, on the Terribile Bank ( $-28 \mathrm{~m}$ ) to the west and on the Graham Bank ( $-9 \mathrm{~m}$ ) to the east; they represent three shoals well known to local fishermen.

On the western portion of this rise we identify ten cone-shaped highs arranged along a NS trending and 3 $\mathrm{km}$ wide belt located from 50 to $60 \mathrm{~km}$ offshore Sciacca (Figure 6a). Some of them are grouped in three clusters roughly aligned in a NW-SE to WNW-ESE direction.

The two cones belonging to the Graham Bank lie in a seafloor between 130 to $180 \mathrm{~m}$ below sea level (bsl) (Figures 4 and 6). The smallest of them represents the remnant of the famous Ferdinandea Island grown up during the 1831 eruption (Figure 6c). It appears as a truncated cone that rises up to $150 \mathrm{~m}$ on the surrounding seafloor. The shoal top is $9 \mathrm{~m}$ bsl on a sub-vertical rocky structure representing the neck of the volcanic cone, placed in the middle of a 30 to $60 \mathrm{~m}$ large flat terrace. No evidences of crater rims and even other points of lava emission (e.g. necks or vents) were identified on the top of the shoal as well as on surrounding slopes. These latter appear very steep and regular without evidences of active erosive process (e.g. gullies or scars), confirming its very young age. No lava flows were identified along the slopes as well as around the base of the cone, which shows an elliptical shape with a NW-SE trending, $700 \mathrm{~m}$ long maximum axis.

The Ferdinandea cone grew up on the southeastern base of a bigger cone. This last represents the largest edifice among the ten mapped since it shows a basal diameter of $1.5 \mathrm{~km}$ with an almost perfect circular shape (Figure 6b). The top lies at $35 \mathrm{~m}$ bsl and is formed by several rocky structures located in the middle of a 50$60 \mathrm{~m}$ deep flat terrace. At about $100 \mathrm{~m}$ of water depth the cone shows a break in slope associated with another terrace that is better evident on the southeastern side of the edifice. The slopes exhibit several evidences of erosive activity proving an older age respect to the Ferdinandea cone; the lowest part of the eastern flank is in fact cut by several gullies up to $150 \mathrm{~m}$ long and $6 \mathrm{~m}$ deep. The low northeaster flank appears characterized by few irregularly shaped scars, probably due to hydrothermal alteration, because of the presence of a fumarole field as shown by the bubbles upraising recorded by multibeam sonar echos in the water column. The seafloor at the base of the western flank shows an irregular morphology due to the presence of a one $\mathrm{km}$ long lava field composed by three or four different lava flows (Figure 6b), the only ones recognised in all the mapped area.

Some $2 \mathrm{~km}$ south of the Graham Bank three other cones were identified (Figure 6a). The northernmost of them shows a crest around the cone, similar to a amphitheatre-shaped crater rim opened westward, at the end of which a small and shallow canyon occurs. This evidence could demonstrate its very old and poly-phasic activity. The top, located at $104 \mathrm{~m}$ bsl, does not present a terrace, while the basal diameter is some $500 \mathrm{~m}$ large. The further two cones are very similar each other showing an almost perfect circular shape with a maximum diameter ranging from 750 to $650 \mathrm{~m}$. Their very similar morphological characteristics allow us to infer a probable coeval activity. The first has the top located $67 \mathrm{~m} \mathrm{bsl}$, while the second one presents the highest point at $76 \mathrm{~m}$ bsl. Both the cones show a terraced area at some $90 \mathrm{~m}$ of depth.

Other two cones are located northward, 2 and 4 $\mathrm{km}$ far from the Graham Bank, respectively (Figure 6a). The tops are 100 and $125 \mathrm{~m}$ bsl while the bases are 650 and $900 \mathrm{~m}$ large, respectively. They have no terraces on top but show several important evidences of gravitational instability along the slopes, confirmed by the presence of hummocky morphologies at their bases.

The last three cones are located northward, about 


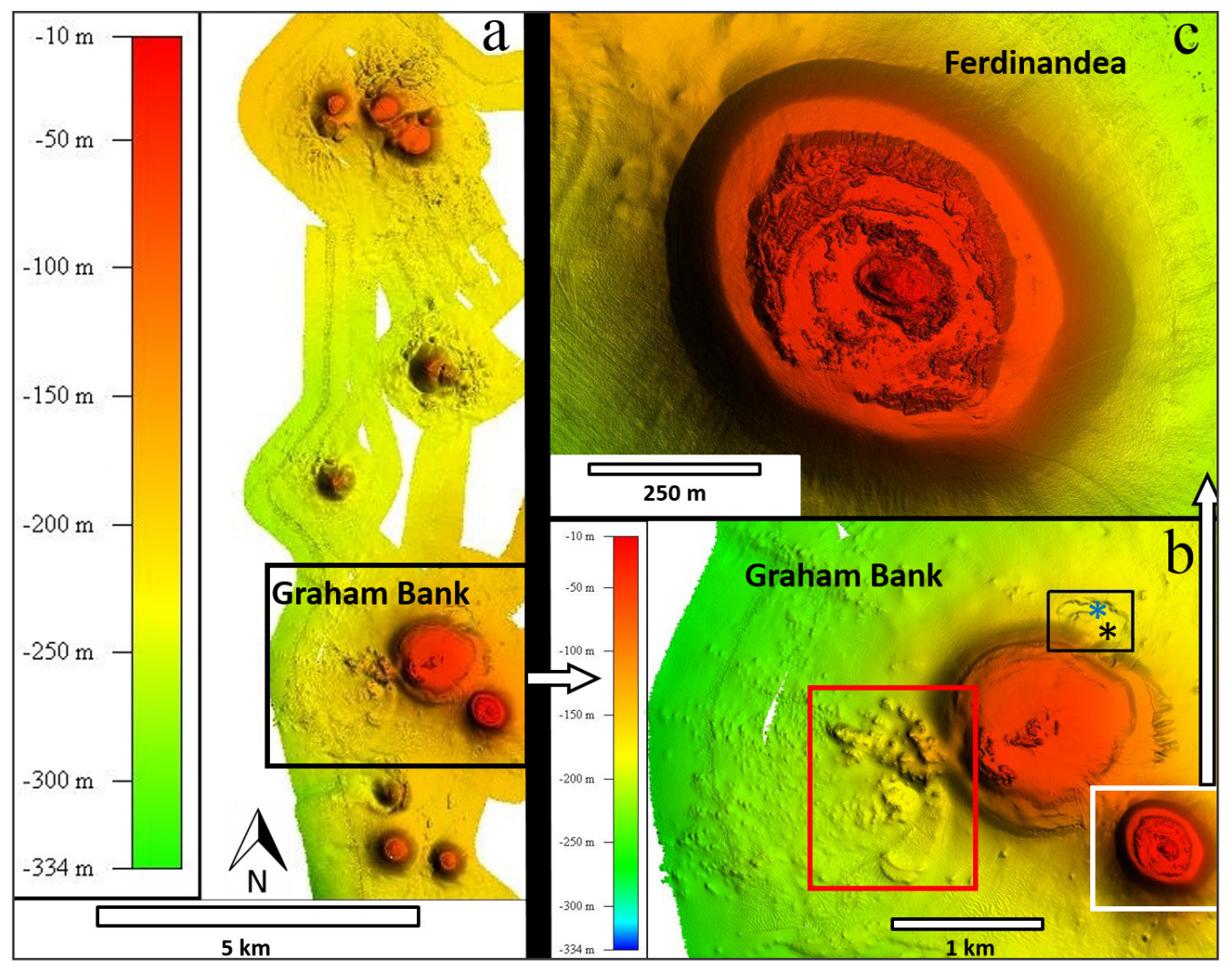

Figure 6. New HR bathymetry images of the volcanic centres identified some $50 \mathrm{~km}$ offshore Sciacca area. (a) The NS trending belt including 10 volcanic cones. (b) The Graham Bank with a lava field (red box) and a fumarole field (black box), located, on its western and northeastern side, respectively; the blue and black asterisks indicate the gas and rock sample locations, respectively. (c) The remnant of Ferdinandea Island.

$8 \mathrm{~km}$ far from the Graham Bank (Figure 6a). They form a group of truncated cones with a flat top terrace at some $80 \mathrm{~m}$ bsl. Their shape is irregular with widths ranging from 500 to $900 \mathrm{~m}$. The slopes show evidence of a very old age due to an intense erosive activity highlighted by the hummocky morphology characterizing the seabottom at their bases. The landslide morphology presents few blocks (up to 200 m large) transported gravitationally downslope. The highest portions of all the cones are characterized by rocky structures corresponding to the necks of the volcanic edifices. Their quite similar morphology allows us to infer a temporally close eruptive activity.

On the Terribile Bank the morphological analysis of the seafloor bathymetry highlights the presence of several scattered frustum-conical shaped structures (often flat on top) showing a smaller size in comparison of the cone-shaped highs of the Graham Bank. Probably they are necks of ancient volcanic cones, confirming the occurrence of an older submarine volcanism affecting this area.

Around the three banks (Graham, Nerita and Terribile) several depressions similar to pockmarks have been also identified (Figure 4); some of them are located at and close to the base of the Graham Bank showing a width up to $100 \mathrm{~m}$ and a depth of 5-6 $\mathrm{m}$. On the southern sector of the Terribile Bank a giant pockmark
(300 $\mathrm{m}$ large and $45 \mathrm{~m}$ deep) was surveyed by ROV, which shows very steep walls cutting the benthonic sediment.

\section{Analysis of seismic activity}

In the framework of the "Ferdinandea 2012" multidisciplinary oceanographic cruise the INGV's staff deployed three broadband OBS/Hs near the Graham, Terrible and Nerita banks to monitor the local seismicity and hydrothermal activity. Several previous OBS/H monitoring campaigns made it possible to characterize the seismic and hydrothermal activity not detected by the onshore seismic network [D'Alessandro et al. 2009, 2012 and 2013]. During this monitoring campaign, lasting about nine months (from July 2012 to March 2013), the submarine stations recorded several regional and teleseismic events but only few local events.

Figure 7 shows two examples of regional and teleseismic events recorded by the OBS/H deployed near Nerita Bank. Due to the moderate environmental noise level, many regional and teleseismic earthquakes have been recorded with a high signal to noise ratio. Such data may be used for the reconstruction of the local crustal velocity models by means of local earthquake tomography and receiver function techniques. However, looking the INGV seismic catalogue, only two earthquakes were located near the OBS/ $\mathrm{H}$ array 

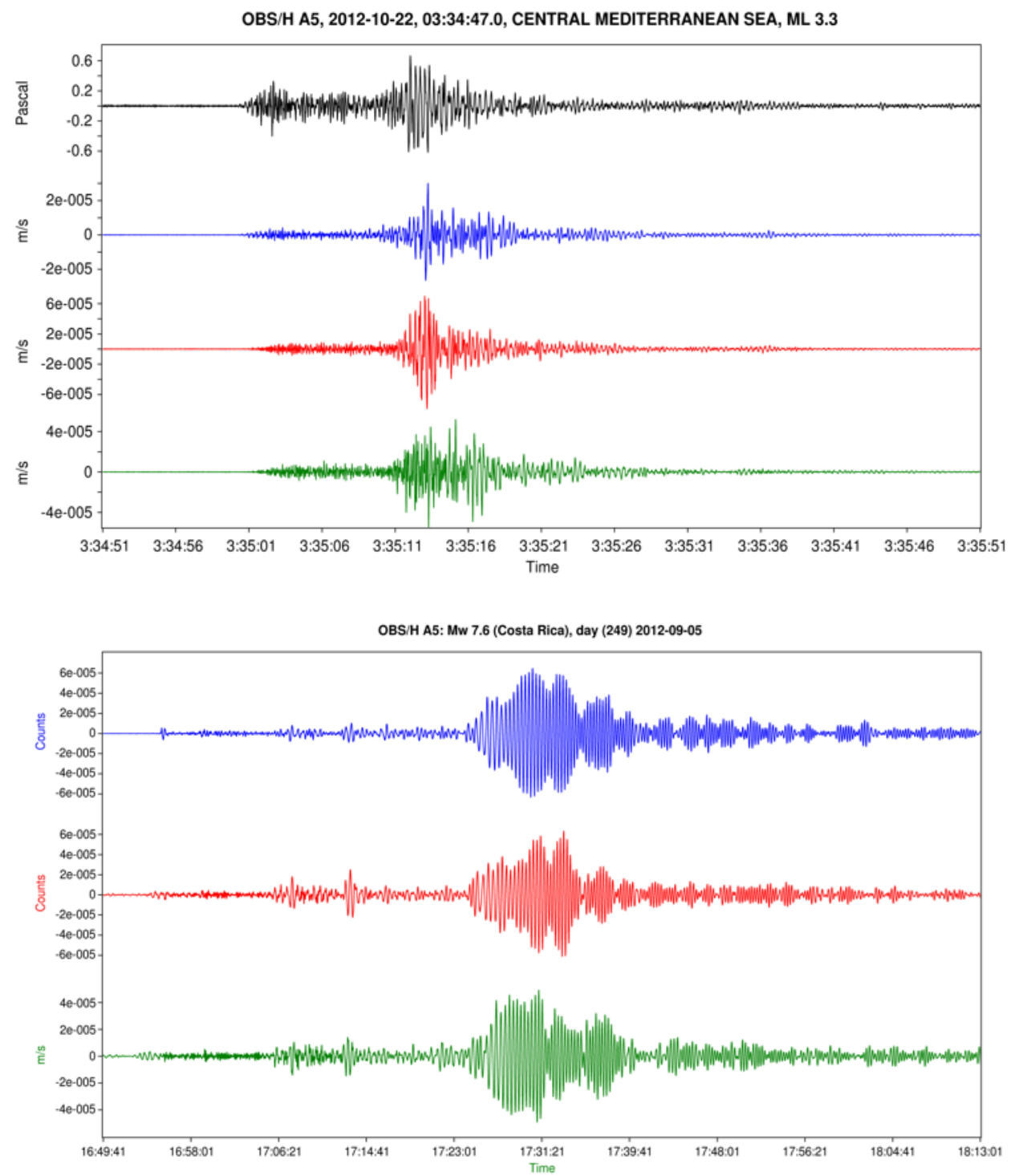

Figure 7. Two examples of a local event (ML 3.3, central Mediterranean Sea) on the left, a teleseismic event ( $\mathrm{M}_{\mathrm{W}}$ 7.6, Costa Rica) on the right, recorded by the OBS $/ \mathrm{H}$ located on the Nerita Bank. Black = pressure, Blue $=$ Up Down, Red $=$ Horizontal 1, Green $=$ Horizontal 2.

(less than $50 \mathrm{~km}$ ). Carefully inspecting the 9 monthslong OBS/Hs recordings, 18 events, not detected by the onshore INGV seismic network, were found. The preliminary location of these events, by means of the single station location technique proposed by D'Alessandro et al. [2013], showed that only 5 of them are located near the OBS/H array. Unlike previous OBS/H monitoring campaigns, like those in the southern Tyrrhenian Sea [D’Alessandro et al. 2009, 2012 and 2013], where several hundred of local seismic events were recorded in few months highlighting an intense local activity, the Graham Bank area seems rather quiet. The lack of local seismicity may support the hypothesis of Calò and Parisi [2014] according to which the large seismic gap in proximity of the Graham Bank (observed in the last 30 years of instrumental seismicity) could be due to a discontinuity in the transfer fault zone crossing western Sicily and the Sicily Channel, even if we cannot exclude that this low seismicity could occur in a period of stress accumulation during a stress accumulation/release cycle.

Several high-frequency events were recorded by the hydrophones; an example of such events is reported in Figure 8. We can observe as such event can last several hours and have a frequency content ranging from 0.5 to over $20 \mathrm{~Hz}$. This high frequency, long duration event may be linked to a temporary intensity increase of the hydrothermal activity; as a matter of fact voluminous rising of gas bubbles were observed on both sonar and ROV images along the NW side of the Graham Bank (see in the following paragraph). The timefrequency analysis of these signals could identify a cyclical behaviour in the local submarine fluid and gas emissions.

\section{ROV dives}

During the cruise some ROV dives were carried out over the slopes of the Graham Bank cones. One of 

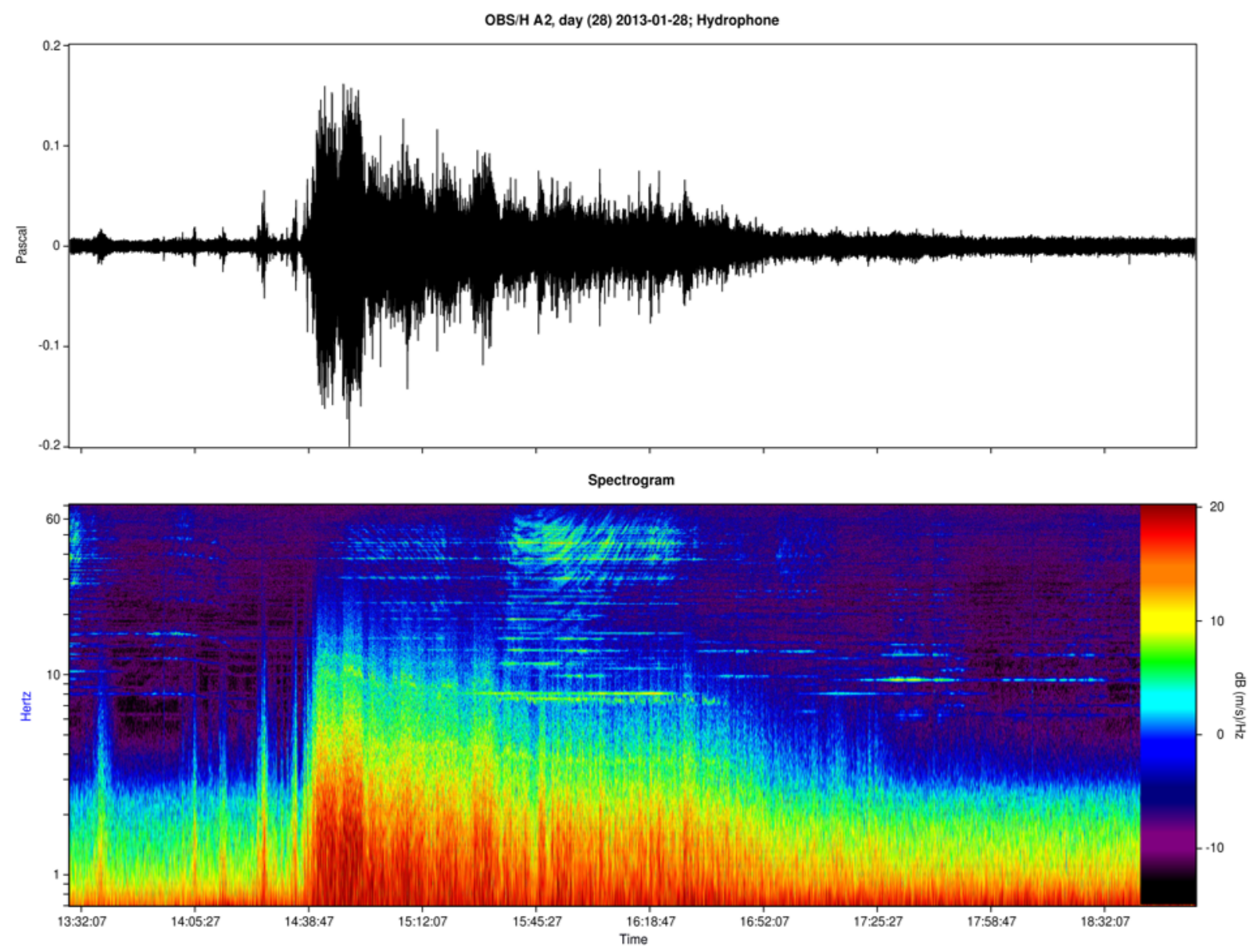

Figure 8. Example of high frequency event recorded by the OBS $/ \mathrm{H}$ located on the Graham Bank. Top = pressure signal, Bottom = relative spectrogram.

them investigated the NW slope of the Ferdinandea cone. The ROV imaged the top terrace of this truncated cone (between 9 and $23 \mathrm{~m}$ of depth) completely covered by a so thick colony of gorgonians that it was no possible to see the rocks where the gorgonians were rooted (being them typical colonizer of rocky morphologies). At about $25 \mathrm{~m}$ bsl a terraced morphology was imaged; it appeared totally covered by a thick layer of black coarse sand organized in ripples of few centimetres in size, most likely deriving from the erosion of 1831 eruption products. On the external boundary of the terrace the ROV imaged some raised morphologies up to 1.5-2 m high made by centimetre undulate layers of consolidate sediments covered by thick colonies of marine organisms. The very steep slopes of the Ferdinandea cone, down to $40 \mathrm{~m}$ of depth, are characterized by consolidate layers of dark sand, sometimes colonized by several organisms; going deeper (down to $-90 \mathrm{~m}$ ) the size of the sediment decreases producing a muddy cover.

Another ROV dive was carried out at the base of the western slope of the largest cone of the Graham Bank, where a lava field was identified on the bathymetric map. The images showed an area, between 130 to $160 \mathrm{~m}$ water depth, widely covered by well-rounded blocks ranging from few decimetres to a couple of meters that were largely incrusted by colonies of marine organisms.

A third ROV dive was carried out along and at the base of the NW slope of the same cone. The investigated area lies at around 150-155 m of depth and is characterized by a muddy to sandy cover with a greybrown colour, sometimes interrupted by white, few meters large, raised morphologies in correspondence of which some bubbles rising occur; they most likely represent the sublimate deposit of the fumaroles activity. At $-155 \mathrm{~m}$ a gas bubbles rising was sampled by using the ROV manipulator (Figure 6) and a glass bottle equipped with a funnel (see Figure 9ab, and the next chapter for the gas analysis).

In the same area, the ROV sampled a piece of a thick crust, which covered the muddy sea bottom (Figure $9 \mathrm{~cd}$ ). It represents a hardened tephra layer, often broken in $1-2 \mathrm{~cm}$ thick large plates, characterized by biogenic concretions on the upper side, whereas the lower side show extensive oxidised surfaces. Tephra is composed of sandy grains, mainly crystals (olivine, minor plagioclase and pyroxene) and two types of glassy particles (one clear with amber colour and the other lightly palagonitized). Probably, they represent the products of the final surtseyan explosive activity of the 1831 eruption. 


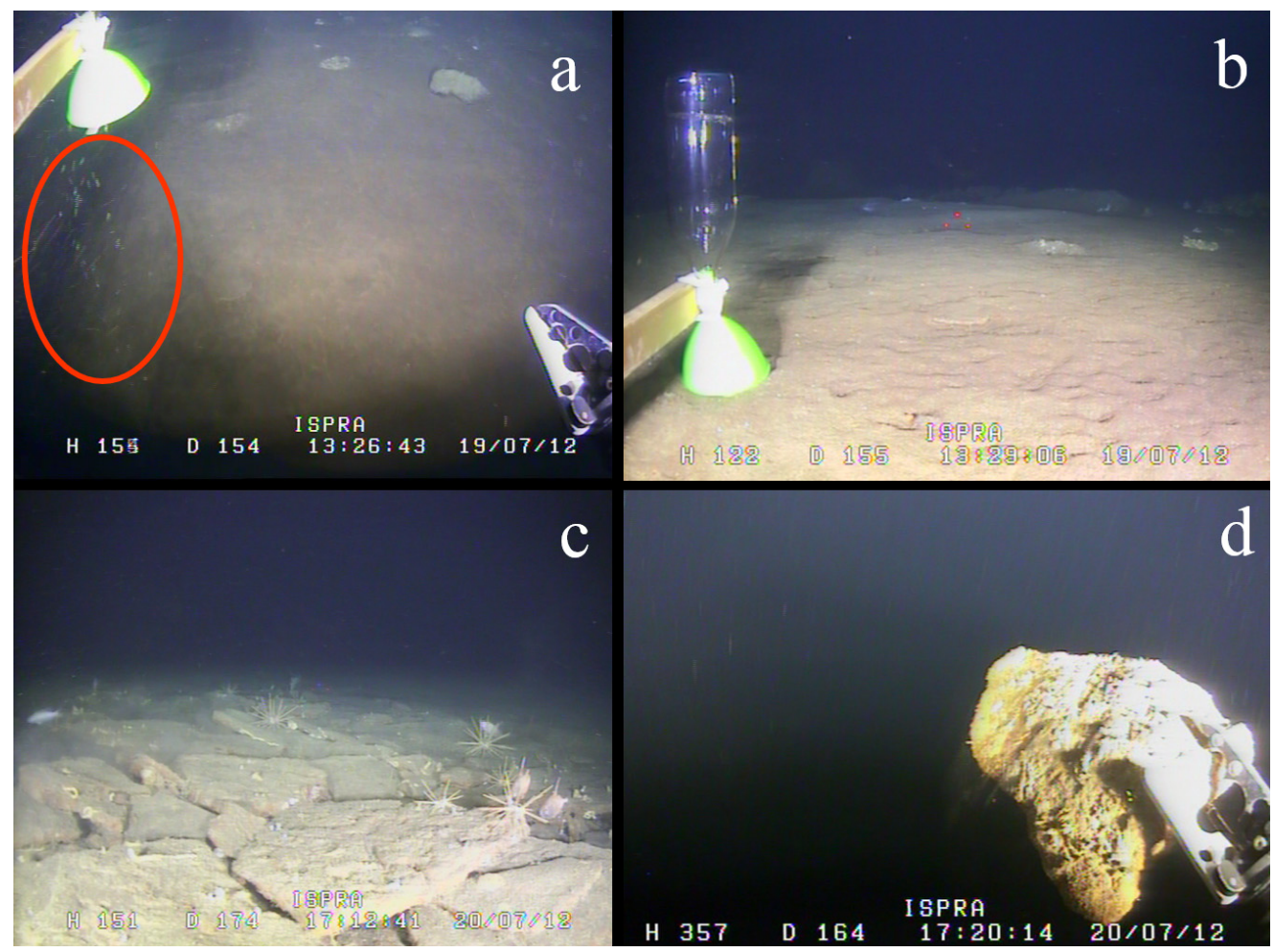

Figure 9. Some pictures showing the different phases of gas bubbles ( $a$ and $b$ ) and seafloor ( $c$ and d) sampling by using the ROV. For location of samples see Figure 6.

\section{Preliminary gas composition}

The chemical composition of the gas sample from the Graham Bank shows the predominance of $\mathrm{CO}_{2}$ $(\sim 73 \mathrm{Vol} \%)$, the rest being $\mathrm{N}_{2}(\sim 16 \mathrm{Vol} \%)$ and $\mathrm{CH}_{4}(\sim 7$ Vol\%). Other species such as $\mathrm{He}_{2} \mathrm{CO}$ and $\mathrm{C}_{2+}$ alkanes are present at ppm level. $\mathrm{H}_{2} \mathrm{O}$, sulphur-bearing gas and halogens were not determined (Table 1).

In the $\mathrm{N}_{2}$-Ar-He classification diagram (Figure 10), the sample shows a marked enrichment in helium content thus converging towards the He corner, typical of mantle gases. The sample also shows a $\mathrm{N}_{2} /$ Ar ratio higher than air and air saturated water (ASW) thus highlighting a slight " $\mathrm{N}_{2}$-excess" likely of organic and/or crustal origin.
The $\mathrm{CO}_{2} /{ }^{3} \mathrm{He}$ ratio $\left(4.3 \times 10^{8}\right)$ is about one order of magnitude lower than typical MORB values $\left(1-8 \times 10^{9}\right.$; Marty and Jambon [1987]). Such a lowering in the $\mathrm{CO}_{2} /{ }^{3} \mathrm{He}$ ratio could be due to the selective dissolution in seawater of highly soluble species such as $\mathrm{CO}_{2}$ that also lead to a relative enrichment in poorly soluble species such as $\mathrm{He}$ and $\mathrm{CH}_{4}$. On the contrary, $\mathrm{CO}_{4} /{ }_{3} \mathrm{He}$ ratio is extremely high, suggesting an additional source for methane.

Both the molecular composition $\left(\mathrm{C}_{1} /\left(\mathrm{C}_{2}+\mathrm{C}_{3}\right) \sim 25\right)$ and the isotope signature of the methane $\left(\delta^{13} \mathrm{C}_{\mathrm{CH}_{4}}=\right.$ -31.8 per mil vs. V-PDB and $\delta \mathrm{D}_{\mathrm{CH}_{4}}=-132.8$ vs VSMOW) are consistent with a derivation of hydrocarbon

\begin{tabular}{|c|c|c|c|c|c|}
\hline \multicolumn{6}{|c|}{ Graham Bank gas sample } \\
\hline $\mathrm{He}$ & 330 & $\mathrm{CO}_{2}$ & 731600 & $\delta \mathrm{D}_{\mathrm{CH}_{4}}$ & -132.8 \\
\hline $\mathrm{H}_{2}$ & 18 & $\mathrm{C}_{2} \mathrm{H}_{6}$ & 2450 & $\mathrm{CO}_{2} /{ }^{3} \mathrm{He} * 10^{\wedge} 8$ & 4.3 \\
\hline $\mathrm{O}_{2}$ & 21000 & $\mathrm{C}_{3} \mathrm{H}_{8}$ & 467 & $\mathrm{CH}_{4} /{ }^{3} \mathrm{He} * 10^{\wedge 10}$ & 1.37 \\
\hline $\mathbf{N}_{2}$ & 163900 & ${ }^{3} \mathrm{He} /{ }^{4} \mathrm{He}$ & 3.72 & $C_{1} /\left(C_{2}+C_{3}\right)$ & 24.3 \\
\hline $\mathrm{CO}$ & 0.5 & $\delta^{13} \mathrm{C}_{\mathrm{CO}_{2}}$ & -1.75 & & \\
\hline $\mathrm{CH}_{4}$ & 70900 & $\delta^{13} \mathrm{C}_{\mathrm{CH}_{4}}$ & -31.8 & & \\
\hline
\end{tabular}

Table 1. Chemical composition and isotope signature of the gas sample collected. All the chemical concentrations are expressed in ppm vol. The helium isotope composition is expressed as $\mathrm{R} / \mathrm{Ra}$, where $\mathrm{R}$ is the ${ }^{3} \mathrm{He} /{ }^{4} \mathrm{He}$ ratio in the sample and $\mathrm{Ra}$ is the same ratio in the atmosphere. The carbon isotope compositions are given in delta per mil versus V-PDB scale. $\delta \mathrm{D}_{\mathrm{CH}_{4}}$ is expressed in delta per mil vs V-SMOW scale. $\mathrm{C}_{1} /\left(\mathrm{C}_{2}+\mathrm{C}_{3}\right)$ is "Barnard parameter" defined as the ratio between methane $\left(\mathrm{CH}_{4}\right)$ and the sum Ethane $\left(\mathrm{C}_{2} \mathrm{H}_{6}\right)+$ Propane $\left(\mathrm{C}_{3} \mathrm{H}_{8}\right)$. 


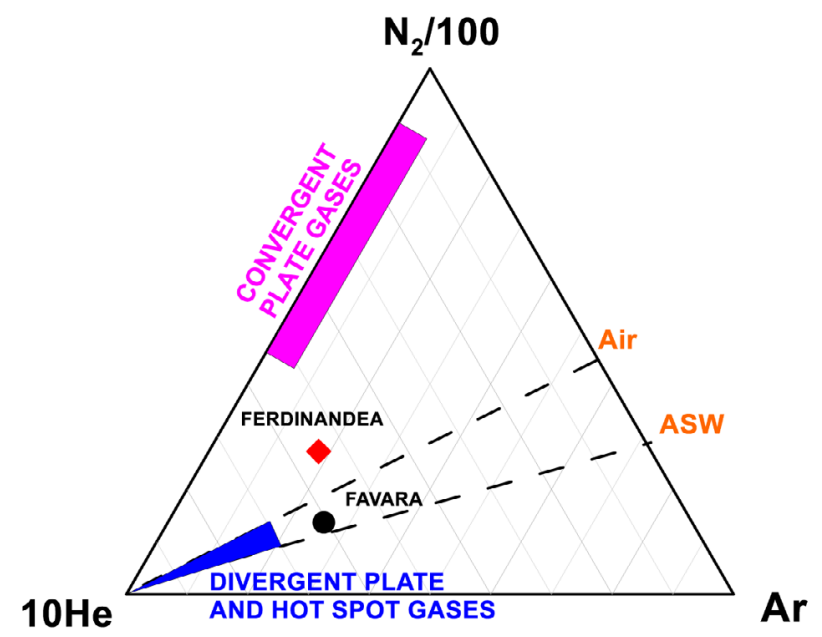

Figure 10. $\mathrm{N}_{2}$-Ar-He ternary plot: the sample from the Graham Bank (red diamond) falls toward the field representative of the gas emitted from volcanism associated to divergent plate (blue field). The $\mathrm{N}_{2} / \mathrm{Ar}$ ratio slightly higher than air suggests the addition of nitrogen, likely organic and/or crustal in origin. For comparison, the sample Favara from Pantelleria Island (black dot) is also reported (data from Parello et al. [2000] and Tassi et al. [2012]); ASW=air saturated water.

gases by thermal cracking of organic matter (Figure 11) [Schoell 1983].

The helium isotope ratio displays a value of 3.72 $\mathrm{Ra}$, which is higher than the typical value of atmosphere and indicates a relevant contribution of mantle-derived helium. A preliminary mass balance computation assuming a ${ }^{3} \mathrm{He} /{ }^{4} \mathrm{He}$ ratio of $0.02 \mathrm{Ra}$ for crustal radiogenic helium and of $7.3 \mathrm{Ra}$ for the local magmatic end-member (i.e. Pantelleria Island; see Parello et al. [2000]) indicates an almost equal proportion between crustal $(\mathrm{f}=0.52)$ and mantle-derived $(\mathrm{f}=0.48)$ helium.

The carbon isotopic composition of $\mathrm{CO}_{2}$ shows a $\delta^{13} \mathrm{C}$ value of $-1.75 \%$ vs. V-PDB. Such value overlaps

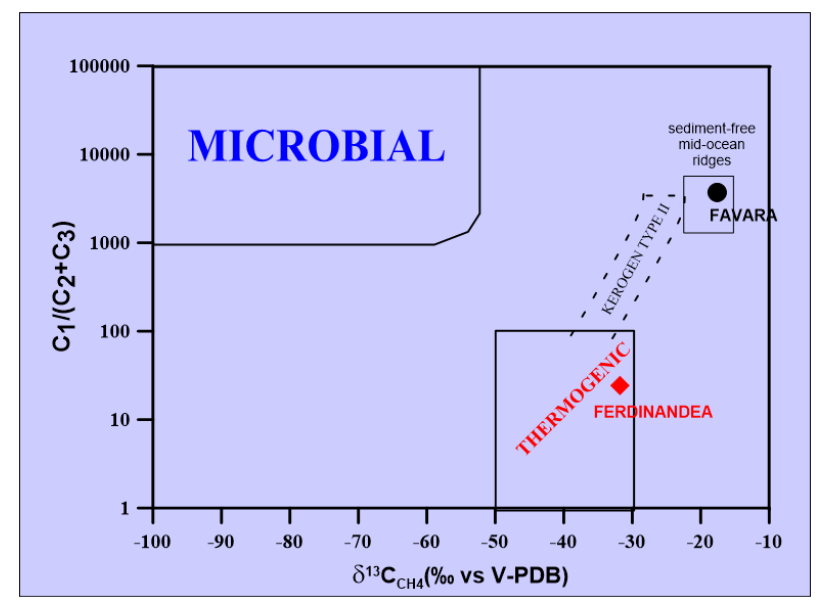

Figure 11. Bernand diagram modified after Tassi et al. [2012]. Methane emitted from the vent close to the Graham Bank (red diamond) is thermogenic in origin and is genetically different from that released from the Favara from Pantelleria Island (black dot) (data from Tassi et al. [2012]). both the carbon isotope composition of magmatic $\mathrm{CO}_{2}$ released from the most active Mediterranean volcanic areas $\left(\delta^{13} \mathrm{C}\right.$ between $-5 \%$ and $0 \%$ ), and that produced by thermo-metamorphic reaction of limestone occurring in the deep crust $\left(\delta^{13} \mathrm{C}=0 \pm 2 \%\right.$; Evans et al. [2008]), suggesting a combined mixed mantle-derived and crustal origin.

Based on the $\log \mathrm{CO} / \mathrm{CO}_{2}$ and $\log \mathrm{CH}_{4} / \mathrm{CO}_{2}$ ratios the sample indicates an equilibrium temperature around $200^{\circ} \mathrm{C}$ under redox conditions controlled by the hydrothermal $\mathrm{fO}_{2}$-buffers [Giggenbach 1987].

The helium and carbon isotope composition indicates that gas emitted from the seafloor in proximity of the Graham Bank reflects a clear magmatic/ crustal origin. Secondary post-genetic processes, such as selective dissolution and mixing with an additional hydrocarbons- and N-rich sedimentary component, have been also identified.

\section{Conclusions and future work}

The "Ferdinandea 2012" oceanographic cruise was the first research activity with a multidisciplinary approach studying the NW sector of the Sicily Channel; it was carried out in the framework of the extension to the sea of the geophysical and geochemical monitoring of the Italian active volcanoes [Favali et al. 2005, Italiano et al. 2011, Mangano et al. 2011].

The new morpho-bathymetric data collected within the "Ferdinandea 2012" cruise show the products of a complex volcanic activity that developed over a period of several thousand years until the historic eruption, occurred in 1831, forming the ephemeral Ferdinandea Island on the Graham Bank. Two volcanic cones form this bank; the eastern one is the remnant of Ferdinandea Island, while another one, more large and complex, lies on the west. The Graham Bank, is not isolated but part of a larger monogenic volcanic cone field which consists of ten small to medium volcanic edifices. They are well structured and highly variable in size and erosive stage, located on a $15 \mathrm{~km}$ long and $3 \mathrm{~km}$ wide NS trending belt and grouped in three small clusters showing a roughly NW-SE to WNW-ESE direction, according to the orientation of the Sicily Channel rift.

The Ferdinandea cone is morphologically the youngest and well-preserved volcanic edifice of the volcanic cones field. The extremely regular morphology of its slopes and the absence of any secondary crater, fissure or simple volcanic vent as well as of supplementary terraces allow us to rule out the occurrence of any eruptive activity or uplift after the 1831 eruption, in contrast with some chronicles that reported other activities on 1833 and 1863 (see Falzone et al. [2009]), thus confirming its monogenic nature. 
During the nine months of the monitoring campaign, very few local earthquakes were located near the Graham, Terrible and Nerita banks. The lack of local seismicity documented by the OBS/Hs recordings as well as that of the last 30 years by ISIDE database, could be due to a tectonic discontinuity in the transfer fault zone crossing western Sicily and the Sicily Channel. This seismic gap is probably related to the local geothermal field and to the volcanic activity, marked by low values of VP, suggesting that the tectonic stress is accommodate differently in these areas [Calò and Parisi 2014], even if the occurrence of a period of low stress release, in a typical accumulation/release cycle, cannot be excluded. Moreover, a strong hydrothermal activity from the Graham Bank was documented by both the direct visual observation with the ROV, and high-frequency events recorded by the hydrophone during the monitoring campaign, indicating a cyclical behaviour of the submarine fluid and gas emissions. Future analyses of regional and teleseismic earthquakes recorded by the OBS/Hs array will be used for the reconstruction of the local crustal velocity model by means of local earthquake tomography and receiver function techniques. This velocity model could confirm and better delimit the low P-wave velocity body recently identified in this area by Calò and Parisi [2014].

The composition of the gas sampled at $-155 \mathrm{~m}$ depth, near the base of the eastern cone of the Graham Bank, indicates a significant mantle component. Helium and carbon isotope compositions show that the gas emitted from the seafloor reflects a clear magmatic/crustal origin, even if secondary post-genetic processes have been also identified. Future samplings and more detailed chemical and isotopic analyses will improve the knowledge of geochemical characteristics of the submarine gaseous emissions and can be used to monitor the temporal evolutions of the fumarole field.

Overall, the collected data from "Ferdinandea 2012" multidisciplinary cruise unequivocally confirm that the Graham Bank is an active volcanic area. It represents the only Italian volcano active in historical times still almost completely unknown and not yet monitored. The final goal of the preliminary study described in this paper is to reach in the medium period the continuous volcano monitoring by integrating the data of the multidisciplinary sensors deployed on the seafloor with the monitoring networks operating inland.

Thus, in the near future, new cruises will be planned in order to carry out a high resolution seafloor mapping of the other volcanic edifice remains identified on the Terribile Bank, as well as to collect some volcanic rock and gas samples from the other volcanic cones mapped during the "Ferdinandea 2012" cruise.
Acknowledgements. We thank for their contribution to the success of "Ferdinandea 2012" research cruise, the captain of the R/V ASTREA Massimo Saporito and his crew, Simone Pietro Canese and the C.L.C. Luigi Manzueto of ISPRA, Andrei Diaconov of SoProMar, Gaspare Falautano president of Lega Navale di Sciacca, Domenico Macaluso diver-group leader of Lega Navale di Sciacca. We are grateful to Giuseppe Passafiume, Stefano Speciale and Roberto D'Anna (INGV-CNT) for their collaboration during the OBS activity and Alessandro Bosman of CNR for his support during the multibeam data processing. The oceanographic cruise "Ferdinandea 2012" was supported by "Studi e Ricerche" 2012-grant of INGV-Osservatorio Etneo.

\section{References}

Argnani, A. (1990). The Strait of Sicily rift zone: foreland deformation related to the evolution of a backarc basin, J. Geodyn., 12, 311-331.

Beccaluva, L., P. Colantoni, P. Di Girolamo and C. Savelli (1981). Upper Miocene submarine volcanism in the Strait of Sicily (Banco Senza Nome), B. Volcanol., 44, 573-581.

Ben-Avraham, Z., A. Nur and G. Cello (1987). Active transcurrent fault system along the north African passive margin, Tectonophysics, 141, 249-260.

Boccaletti, M., G. Cello and L. Tortorici (1987). Transtensional tectonics in the Sicily Channel, J. Struct. Geol., 9, 869-876.

Bottari, C., S.C. Stiros and A. Teramo (2009). Archaeological evidence for destructive earthquakes in Sicily between 400 B.C. and A.D. 600, Geoarchaeology, 24 (2), 147-175.

Burollet, P.F., J.M. Mugniot and P. Sweeney (1978). The geology of the Pelagian block: the margins and basins of southern Tunisia and Tripolitania, In: A.E.M. Nairn, W.H. Kanes and F.G. Stelhi (eds.), The Ocean Basins and Margins. The Western Mediterranean, Plenum, New York, vol. 4b, 331-359.

Calanchi, N., P. Colantoni, P.L. Rossi, M. Saitta and G. Serri (1989). The Strait of Sicily continental rift system: physiography and petrochemistry of the submarine volcanic centers, Mar. Geol., 87, 55-83.

Calò, M., and L. Parisi (2014). Evidence of a lithospheric fault zone in the Sicilian Channel continental rift (southern Italy) from instrumental seismicity data, Gephys. J. Int., 199, 219-225.

Cello, G. (1987). Structure and deformation processes in the Strait of Sicily "rift zone", Tectonophysics, 141, 237-247.

Civile, D., E. Lodolo, L. Tortorici, G. Lanzafame and G. Brancolini (2008). Relationships between magmatism and tectonics in a continental rift: the Pantelleria Island region (Sicily Channel, Italy), Mar. Geol., 251, 32-46.

Civile, D., E. Lodolo, D. Accettella, R. Geletti, Z. BenAvraham, M. Deponte, L. Facchin, R. Ramella and 
R. Romeo (2010). The Pantelleria graben (Sicily Channel, central Mediterranean): an example of intraplate 'passive' rift, Tectonophysics, 490, 173-183.

Colantoni, P., M. Del Monte, P. Gallignani and E.F.K. Zarudzky (1975). Il Banco Graham: un vulcano recente nel Canale di Sicilia, G. Geol., 40 (1), 141-162 (in Italian).

Conte, A.M., E. Martorelli, M. Calarco, A. Sposato, C. Perinelli, M. Coltelli and F.L. Chiocci (2014). The 1891 submarine eruption offshore Pantelleria Island (Sicily Channel, Italy): Identification of the vent and characterization of products and eruptive style, Geochem. Geophys. Geosyst., 15 (6), 2555-2574; doi:10.1002/2014GC005238.

Corti, G., M. Cuffaro, C. Doglioni, F. Innocenti and P. Manetti (2006). Coexisting geodynamic processes in the Sicily Channel, In: Y. Dilek and S. Pavlides (eds.), Postcollisional tectonics and magmatism in the Mediterranean region and Asia, Geol. Soc. Am. Spec. paper 409, 83-96.

D’Alessandro, A., G. D’Anna, D. Luzio and G. Mangano (2009). The INGV's new OBS/H: analysis of the signals recorded at the Marsili submarine volcano, J. Volcanol. Geoth. Res., 183 (1-2), 17-29; doi:10.1016/ j.jvolgeores.2009.02.008.

D’Alessandro, A., D. Luzio, G. D'Anna and G. Mangano (2011). Seismic Network Evaluation through Simulation: An Application to the Italian National Seismic Network, B. Seismol. Soc. Am., 101 (3), 1213-1232; doi:10.1785/0120100066.

D’Alessandro, A., G. Mangano and D’Anna (2012). Evidence of persistent seismo-volcanic activity at Marsili seamount, Annals of Geophysics, 55 (2), 213-214; doi:10.4401/ag-5515.

D’Alessandro, A., G. Mangano, G. D'Anna and D. Luzio (2013). Waveforms clustering and single-station location of microearthquake multiplets recorded in the northern Sicilian offshore region, Geophys. J. Int., 194 (3), 1789-1809; doi:10.1093/ gji / ggt192.

Evans, M.J., L.A. Derry and C. France-Lanord (2008). Degassing of metamorphic carbon dioxide from the Nepal Himalaya, Geochem. Geophys. Geosyst., 9, Q04021; doi:10.1029/2007GC001796.

Falzone, G., G. Lanzafame and P.L. Rossi (2009). Il vulcano Ferdinandea nel Canale di Sicilia, Geoitalia, 29, 15-20 (in Italian).

Favali, P., L. Beranzoli, G. D’Anna, F. Gasparoni and W. Gerber Hans (2005). NEMO- SN-1 the first "real-time" seafloor observatory of ESONET, Nucl. Instrum. Meth. A, 567, 462-467.

Finetti, I.R. (1984). Geophysical study of the Sicily Channel rift zone, B. Geofis. Teor. Appl., 12, 263-341.

Gemellaro, C. (1831). Relazione dei fenomeni del nuovo vulcano sorto dal mare fra la costa di Sicilia e l'Isola di Pantelleria nel mese di luglio 1831, Catania, Ne' torchi della Regia Università, 48 p. + Appendix, 25 p. (in Italian).

Giggenbach, W.F. (1987). Redox processes governing the chemistry of fumarolic gas discharges from White Island, New Zeland, Appl. Geochem., 2, 143-161.

Guidoboni, E., A. Muggia, C. Marconi and E. Boschi (2002). A case study in archaeoseismology. The collapses of the Selinunte temples (Southwestern Sicily): two earthquakes identified, B. Seismol. Soc. Am., 92 (8), 2961-2982.

Guidoboni, E., G. Ferrari, D. Mariotti, A. Comastri, G. Tarabusi and G. Valensise (2007). CFTI4Med, Catalogue of strong earthquakes in Italy (461 B.C.-1997) and Mediterranean area (760 B.C.-1500), INGVSGA; http://storing.ingv.it/ cfti4med/ .

Illies, J.H. (1981). Graben formation - the Maltese Islands - a case history, Tectonophysics, 73, 151-168.

Italiano, F., R. Maugeri, A. Mastrolia and J. Heinicke (2011). SMM, a new seafloor monitoring module for real-time data transmission: an application to shallow hydrothermal vents, Procedia Earth and Planetary Science, 4, 93-98.

Jongsma, D., J.E. Van Hinte and J.M. Woodside (1985). Geologic structure and neotectonics of the North African continental margin south of Sicily, Mar. Petrol. Geol., 2, 156-179.

Lentini, F., S. Carbone and P. Guarnieri (2006). Collisional and postcollisional tectonics of the ApenninicMaghrebian orogen (southern Italy), In: Y. Dilek and S. Pavlides (eds.), Postcollisional tectonics and magmatism in the Mediterranean region and Asia, Geol. S. Am. S., 409, 57-81; doi:10.1130/2006.2409(04).

Mangano, G., A. D’Alessandro and G. D’Anna (2011). Long term underwater monitoring of seismic areas: Design of an Ocean Bottom Seismometer with Hydrophone and its performance evaluation. OCEANS, 2011 IEEE - Spain; ISBN: 978-53 1-4577-0086-6, doi:10.1109/Oceans-Spain.2011.6003609.

Marty, B., and A. Jambon (1987). C $/{ }^{3} \mathrm{He}$ in volatile fluxes from the solid Earth: implication for carbon geodynamics, Earth Planet. Sci. Lett., 83, 16-26.

Marzolla, B. (1831). Descrizione dell'Isola Ferdinandea al mezzogiorno della Sicilia, Reale Officio Topografico, Napoli, 4 p. (in Italian); reprinted with a preface by I. Friedlaender in: Zeitschrift für Vulkanologie, vol. 5, Vulkanische Ereignisse und Bibliographie, Berlin, D. Reimer Verlag, 1920, 40-50.

Meletti, C., F. Galadini, G. Valensise, M. Stucchi, R. Basili, S. Barba, G. Vannucci and E. Boschi (2008). A seismic source zone model for the seismic hazard assessment of the Italian territory, Tectonophysics, 
450, 85-108

Ogniben, L. (1969). Schema introduttivo alla geologia del confine calabrolucano, Mem. Soc. Geol. Ital., 8, 435-763 (in Italian).

Parello, F., P. Allard, W. D’Alessandro, C. Federico, P. Jean-Baptiste and O. Catani (2000). Isotope geochemistry of Pantelleria volcanic fluids, Sicily Channel rift: a mantle volatile end-member for volcanism in southern Europe, Earth Planet. Sci. Lett., 180, 325-339.

Reuther, C.D., and G.H. Eisbacher (1985). Pantelleria rift-crustal extension in a convergent intraplate setting, Geol. Rundsch., 74, 585-597.

Reuther, C.D., Z. Ben-Avraham and M. Grasso (1993). Origin and role of major strike-slip transfers during plate collision in the central Mediterranean, Terra Nova, 5 (3), 249-257.

Rigano, R., L. Arena, M.S. Barbano, B. Antichi and R. Azzaro (1998). Sismicità e zonazione sismogenetica in Sicilia occidentale, In: GNGTS - Atti del $17^{\circ}$ Convegno Nazionale - 12.04, extended abstracts, 161-162.

Rotolo, S.G., F. Castorina, D. Cellula and M. Pompilio (2006). Petrology and geochemistry of submarine volcanism in the Sicily Channel, J. Geol., 114, 355-365.

Rovida, A., R. Camassi, P. Gasperini and M. Stucchi, eds. (2011). CPTI11, the 2011 version of the Parametric Catalogue of Italian Earthquakes, Milano/Bologna; http: / / emidius.mi.ingv.it/CPTI.

Schoell, M. (1983). Genetic characterization of natural gases, AAPG Bulletin, 67, 2225-2238.

Tassi, F., J. Fiebig, O. Vaselli and M. Nocentini (2012). Origins of methane discharging from volcanic-hydrothermal, geothermal and cold emissions in Italy, Chem. Geol., 310-311, 36-48.

Torelli, L., M. Grasso, G. Mazzoldi, D. Peis and D. Gori (1995). Cretaceous to Neogene structural evolution of the Lampedusa shelf (Pelagian Sea, Central Mediterranean), Terra Nova, 7, 200-212.

Washington, H.S. (1909). Submarine Eruptions 1831 and 1891 near Pantelleria, Am. J. Sci., IV, 27, 131-150.

\footnotetext{
${ }^{\star}$ Corresponding author: Mauro Coltelli,

Istituto Nazionale di Geofisica e Vulcanologia, Osservatorio Etneo, Catania, Italy; email: mauro.coltelli@ingv.it.

(C) 2016 by the Istituto Nazionale di Geofisica e Vulcanologia. All rights reserved.
} 